УДК 347.6

DOI https:/ / doi.org/10.32837/yuv.v0i3.1950

Х. Солодовнікова,

кандидат психологічних наук, юрист наукової теми

Інституту права

Київького національного університету імені Тараса Шевченка

\title{
ПРАВО НА ІНФОРМАЦІЮ ПРО ПОХОДЖЕННЯ: ЗАКОРДОННИЙ ДОСВІД
}

В умовах глобалізованого сьогодення та стрімкої діджиталізації всіх сфер суспільного життя нагальною постає проблема виваження пріоритетів таких природних прав людини, які лежать в основі фундаментального права на повагу до приватного життя, як право на конфіденційність (або в деяких країнах - анонімність) та право знати своє походження. Зокрема, поширеною є практика, яку виведено у Конституцію однієї з країн ЄC - Португалії від 1975 р., котра містить норму: «Усі мають право належати своїи сім’і, знати своїх батьків». Позиція Конституційного суду цієї країни висловлена ним у справі № 631-2005 від 15.11.2005: «Знання свого батька і своєї матері $€$ необхідним елементом основного права дитини на вільний розвиток іi особистості 3 того погляду, що дає змогу особі жити особистою історією як цілісній особистості, історією спадкування генів і створювати власну сім’ю».

Традиційно в українській правовій доктрині вважається, що «походження» - це наявність біологічного зв'язку дитини і батьків. Проте не слід змішувати «народження дитини» та іï «походження» (Т.А. Фаддєєва), подію (народження дитини) і юридичний склад (установлення походження дитини від батька і матері). Під терміном «походження дітей» розуміють біологічне походження дитини від конкретних чоловіка і жінки, зареєстроване в органах реєстрації актів цивільного стану з дотриманням певного порядку та згідно із законодавством.

Забезпечення права дитини на інформацію про власне походження, тобто на інформацію про батьків дитини, грунтується на визначенні, хто є батьками дитини. Так, Програма ЮНІСЕФ щодо роз'яснення та імплементації норм Конвенції наводить такі категорії батьків: генетичні (особи, які надали біологічний матеріал під час запліднення дитини, наприклад донор яйцеклітини); біологічні (мати, яка народила дитину, і батько, який перебував у шлюбі чи інших взаємовідносинах із матір'ю і визнав батьківство щодо дитини) і психологічні або соціальні (особи, які доглядають і виховують дитину, маючи з нею певний юридичний зв'язок, наприклад опікуни, усиновлювачі) [1, с. 105]. Така класифікація прийнятна для визначення обсяг взаємних прав та обов'язків між дитиною і кожною категорією батьків.

Уперше увагу до цієї проблеми було приділено в тій частині міжнародного права, що присвячена правам дитини [2]. Це, зокрема, Конвенція про права дитини від 20.11.1989. Так, п. 1 ст. 7 говорить про право дитини знати своїх батьків, наскільки це можливо, а також право на їх піклування (ст. 69) [3]. Проте, як слушно зауважує К. Москаленко, тут йдеться скоріше про правовий зв'язок батьків із дитиною, а не біологічний: «Ст. $7 \mathrm{Koн-}$ венції про права дитини гарантує 
дитині право, «наскільки це можливо, знати своїх батьків». На нашу думку, відповідне формулювання не гарантує дитині право знати своїх біологічних батьків, адже термін «батьки», який уживається у Конвенціі, стосується саме осіб, які мають правовий зв'язок із дитиною, а не біологічний» [4].

Пізніше це право у більш чіткому формулюванні було прописано у Гаазькій конвенції про захист дітей та співробітництво щодо їх закордонного усиновлення від 29.95.1993. Стаття 30 даної Конвенції прямо покладає обов'язок щодо забезпечення збереження наявної інформації про походження особи на відповідні компетентні державні органи (п. 1), а п. 2 [5] зазначеної статті покладає на ці органи обов'язок забезпечення доступу до такої інформації в межах, установлених законодавством цієї держави [6], із застереженням, що таку інформацію може і не бути надано, це залежить від національного законодавства. Як приклад професор факультету міжнародного права в Лондонському університеті Королеви Марії Джеральдин ван Бюрен у своїй науковій праці, присвяченій дослідженню міжнародного законодавства у сфері прав дитини, наводить Шрі-Ланку, де надання зазначеної інформації прирівнюється до порушення конфіденційності і може нести загрозу життю біологічної матері [7].

Таким чином, можна говорити про те, що вищезгадана Конвенція зобов'язує країни-учасниці на міжнародному рівні, проте покладає вирішення організаційних питань із надання доступу до цієї інформації на національне законодавство.

Європейська конвенція про усиновлення від 27.11.2008 (Страсбург) визнає, що дитина має право знати своє походження, а також має право на доступ до такої інформації, яка $€$ у держави. Зазначається, що хоча батьки мають право на конфіденційність, проте компетентні органи держави повинні мати можливість у межах закону встановлення їх особистості та надавати доступ до такої інформації [8].

Що ж до права на інформацію про власне походження загалом (не лише дітей), то тут європейське законодавство та юридична практика керуються принципами, викладеними в тексті Європейської конвенції про захист прав та осоновоположних свобод від 1950 р. Зокрема, хоча у згаданій Конвенції чітко не регламентоване право на знання про своє походження, проте практика ЄСПЛ свідчить про те, що судді керуються нормами, викладеними у ст. 8 даної Конвенції, в якій йдеться про право на повагу приватного та сімейного життя. Слід наголосити на тому, що судді ЄСПЛ, приймаючи рішення щодо «приватного життя», виходять із того, що обов'язковими атрибутами даної правової формули є психічна, фізична цілісність особи, а також іiі ідентичність [9]. Зокрема, Суд установив, що жінка має право на захист своїх ембріонів, оскільки вони становлять ії фізичну та особисту цілісність (справи про вимушені аборти). Так само Суд трактує дану правову формулу в межах права на знання про походження (у справі Гаскін проти Сполученого Королівства (Gaskin v. United Kingdom), Одьювр проти Франціï (Odievre v. France), Джаггі проти Швейцарії (Jaggi v. Switzerland), Leyla Can v. Türkey [10], Gozum v. Türkey тощо).

У справі «Одьювр проти Франції» Європейський суд із прав людини у своєму рішенні від 13.02.2003 підкреслив складність та делікатність реалізації означеного права. Суд наголосив також, що для кожного це право «мати свою історію, свій вибір біологічних батьків, існуючі сімейні зв'язки та зв'язки батьків, що усиновлюють» [11]. Тому складність тут полягає у віднайденні балансу між цим правом особи на знання походження та правом матері на захист конфіденційності (таємності материнства). 
Віднайдення та реалізацію цього балансу має бути покладено на національне законодавство за збереження рівноваги між державними інтересами та інтересами особи, зокрема враховуючи положення ст. 8 вищезгаданої Конвенції про повагу до приватного і сімейного життя.

Аналіз конституційного права держав Західної Європи, на думку французького дослідника В. Шиу, дає підстави стверджувати, що сьогодні консенсус між суддями конституційних судів різних держав відсутній [2].

Так, науковець дійшов висновку, що в деяких країнах пріоритет надається принципу анонімності (l'anonymat). Це такі країни, як Франція, Італія, Люксембург. Учений зазначає, що, згідно із цим принципом, національне законодавство цих країн відмовляє в реалізації права знати походження в його конституційному значенні. Дослідник констатує відсутність конструктивного діалогу між конституційними судами даних країн та їніми колегами $з$ інших країн, що дотримуються протилежних поглядів щодо цього права. Зокрема, у царині ЄСПЛ, де наполягають на дотриманні права знати походження і засуджують італійське законодавство за відсутність намірів щодо віднайдення балансу між правом матері на анонімність та правом знати походження. Зазначимо, що тут не йдеться про охорону анонімності батьківства, натомість підкреслюється, що в Італії мати дитини має право на анонімність у закладах охорони здоров'я (лікарнях) і при народженні дитини.

Протилежної думки дотримуються конституційні суди інших країн, а саме Нідерландів, Португалї, Німеччини, Норвегії, Бельгії, Іспаніі, у чотирьох останніх країнах дане право регламентоване нормами Основного Закону. При народженні дитини інформація про батьків автоматично фіксується в акті про народження.

В основі такого підходу до права на знання походження лежать повага до особистості, визнання гідності особи, що грунтуються на праві особистої ідентичності та праві на особистий розвиток. Зокрема, за результатами аналітичних розвідок було встановлено той факт, що це право є складовою частиною людської гідності. Так, Конституційний суд Норвегії визначив право на знання свого походження основою гідності людини. Подібної позиції притримується Федеральний Конституційний суд Німеччини, який обгрунтував свою позицію у п. 1 ст. 2 Основного Закону ФРН від 23.05.1949: «Кожен має право на вільний розвиток своєї особистості за умови, що він не порушує прав інших осіб i не порушує конституційний лад чи морального закону» [12]. Так само 3 положень Конституції дане право виводить Верховний суд Нідерландів. Федеральний Конституційний суд ФРН дав пояснення даного права у своїх рішеннях, датованих 1994 та 1997 pp.

Конституційний суд Іспанії у своїх рішеннях від 21.09.1999 заборонив анонімність матері при народженні дитини, у рішенні від 22.05.2000 підкреслив право дитини на знання своїх біологічних батьків. Подібну категоричну позицію у цій сфері має Федеральний суд Швейцарії серією своїх рішень від 1992 р., який обгрунтовує iї нормами Конституції своєї держави.

В. Шиу, аналізуючи національне законодавство зазначених країн, навіть виділив право на знання походження в окрему категорію, яку назвав «квазіабсолютною» цінністю [2].

Найбільш гостро проблематика щодо права на знання походження постає у так званих «дітей із пробірки». Німецькі дослідники вбачають загострення цієї проблеми, виходячи зі стрімкого розвитку науково-технічного прогресу та статистичних даних про погіршення репродуктивного здоров'я у країнах Західної Європи.

Так, широке коло правових питань у даній сфері окреслюють Б. Циприс та М. Цееб. Вони відзначають 
необхідність змін правового регулювання донорства сперми виходячи 3 аналізу ситуації, що склалася в Німеччині в умовах заборони донорства яйцеклітин та сурогатного материнства, згідно із Законом «Про захист ембріонів» від 13 грудня 1990 р. [13], яким закріплено заборону використання сурогатного материнства і введено суттєві обмеження стосовно застосування допоміжних репродуктивних технологій [14]. Слід зазначити, що в німецькому законодавстві існують паралельно дві дефініції поняття «ембріон», а саме в абз. 1 $\S 8$ («Визначення понять») Закону Федеративної Республіки Німеччина (далі - ФРН) «Про захист ембріона» (Embrzonenschutzgesetz) [13], та визначення, застосоване у нормі п. 4 § Закону ФРН «Про забезпечення захисту ембріона у зв'язку з імпортом та застосування людських ембріональних стовбурових клітин» (Закон про стовбурові клітини Stammzellgesetz (StZG)) [15].

Дотримуючись закону про охорону материнства в Німеччині, всі різновиди сурматеринства заборонені в усіх федеральних землях Німеччини, дане діяння підлягає кримінальній відповідальності. Проте німецький законодавець не врахував усіх сучасних медичних можливостей та, відповідно, не повністю врегулював питання в даній сфері.

Як свідчать нещодавні події в Україні, коли під час карантину іноземні матері не мали доступу до дітей, народжених сурогатними матерями, одним із варіантів може стати участь у програмах сурматеринства в інших країнах. Правові наслідки в такому разі можуть бути такими, що після появи дитини за участю сурогатної матері біологічним батькам важко завести ії на територію своєї країни. Це пов'язано з тим, що справжніми батьками за законодавством Німеччини вважаються сурогатна матір та іiі чоловік, незважаючи на те що дитина їм генетично чужа. Малюк також автоматично отримує громадянство матері, що його народила. Тож, згідно з німецьким законодавством, біологічна мати не має ніяких юридичних прав на таку дитину.

Німецькі вчені Б. Циприс та М. Цеєб уважають, що потреба врегулювати питання ідентифікації донорства сперми стоїть перед німецьким цивільним законодавством уже зараз, оскільки в майбутньому, із подальшим поширенням юрисдикції права ЄС, ці проблеми стануть транскордонними, а діти, народжені за таких умов, не будуть обмежені національними кордонами [16].

Дослідники зауважують, що актуальною проблемою $є$ питання, хто саме має право на декретну відпустку по догляду за новонародженою дитиною: сурогатна, соціальна чи юридична мати. Так, у своєму Консультативному висновку Страсбурзький суд пропонує гармонізувати національне законодавство Франції з метою недопущення порушення прав дитини [17].

У своїй науковій розвідці Б. Циприс та $M$. Цеєб наводять приклад багатошаровості даної проблематики. Зокрема, йдеться про судову практику, де вищий суд землі Дюссельдорф розглядав справу щодо включення в реєстр новонародженої дитини, що з'явилася на світ за кордоном від німця, котрий надав свою сперму для запліднення яйцеклітини, яку надалі пересадили сурогатній матері. Незважаючи на делікатність та складність означених проблем, німецькі науковці наполягають на пріоритеті права дитини знати походження [16].

Аналізуючи німецьке законодавство, яке покликане врегулювати суспільні відносини щодо права знати походження, є підстави стверджувати, що воно в першу чергу орієнтоване на охорону природного, конституційно охоронюваного права кожного знати про своє генетичне походження. Ця теза грунтується на рішеннях Федерального Конституційного Суду 
Німеччини (1988 та 1989 рр.), де зазначено важливість знання про генетичне походження для індивідуалізації та саморозуміння особистості.

$\mathrm{У}$ зазначеній роботі автори пропонують детальний план запровадження в німецьке законодавство процедур, що регламентують окремі відносини щодо реалізації права на знання походження із частковим збереженням анонімності донорів (сперми).

Зокрема, пропонується запровадження таких кроків, як: обмеження комерційного донорства із застереженнями про медичний контроль над ним; заборона анонімного донорства й використання змішаної сперми; заборона ліквідації даних про донорів; централізоване довготривале (пропонується аж до 100 років) зберігання даних про донорство не лише лікарями, а й при установах, що провадять збір сперми; спеціальні повноваження нотаріуса 3 метою його посередництва між заінтересованими особами [16].

Цікавою видається пропозиція щодо того, що донором може стати виключно особа, яка психологічно готова в майбутньому контактувати 3 дитиною, тобто порушити свою конфіденційність. Окрім того, що сьогодні вже наявна державна підтримка батьків в особі компетентних органів, така підтримка пропонується й тим, хто лише готується стати батьками, а саме у вигляді психологічної, соціальної, юридичної консультації компетентними установами.

На думку вищезгаданих дослідників, удосконалення законодавства Німеччини дасть змогу вирішити цілу низку проблем, які $€$ актуальними: вирішення спорів щодо позбавлення або надання права на батьківство донорам на противагу сучасному стану, коли, згідно з нормами $\$ 1598$ та Цивільного кодексу ФРН [18], дитина має право претензійної вимоги виключно юридично визначеним батькам [19]; вирішення питань генетичного походження за умови донор- ства від двох і більше донорів; урегулювання питань походження дитини в одностатевих шлюбах; визнання батьківства ще до народження дитини (п. 4 ст. 1594 ЦК ФРН) [20].

Представники німецької доктрини права наголошують, що знання свого походження $€$ одним 3 елементів, необхідних і важливих для розвитку особистості, гідного людини. Знання про походження може зайняти у свідомості індивіда ключову позицію його самоусвідомлення [21]. Хоча загальне право на власну особистість не дає особі право вимагати від будького надання відомостей про власний родовід, воно, проте, захищає індивіда від того, що інформацію буде приховано [22]. Наприклад, рішення про те, чи має право матері приховати ім'я батька своєї позашлюбної дитини пріоритет перед правом самої цієї дитини на відповідну інформацію, не так просто вивести суто з гарантій основних прав, натомість воно лежить у межах регуляторного простору законодавця, і якщо він такого рішення не прийняв, його, за потреби, повинні ухвалити спеціалізовані суди [23]. Загальне право особистості дає змогу дитині, яку зачали гетерологічним заплідненням, як правило, вимагати від лікаря-репродуктолога ім'я іï біологічного батька [24].

Отже, є підстави стверджувати, що науково-практична дискусія щодо виваженості пріоритетів всередині права на повагу до приватного життя, а саме анонімність та право знати походження, ще не має чітких правових результатів. Проте певні країни вже визнають право на інформацію про походження конституційним. А віднайдення балансу збереження інтересів дитини й анонімність батьків пропонується за допомогою збереження останньої до настання 16-річного віку дитини, після чого дитина набуває право на дану інформацію. Такий законопроєкт було внесено до Бундестагу від 19.03.2013. 
У цілому в світі спостерігається тенденція на обмеження таємниці біологічного походження, а пріоритет набуває право на отримання інформації про походження.

У науковій літературі здебільшого дискутується питання щодо права на інформацію дитини про походження, тодi як сучасний закордонний досвід, зокрема Німеччини, свідчить про те, що повний доступ до иього права має належати людині після 16 років, оскільки німецька доктрина права обтрунтовує, що саме у цьому віці людина більшою мірою психологічно готова до сприйняття такої інформації, а отже, набуває розширених можливостей щодо соціальної, правової тощо його реалізащії.

Що ж до інформаціі про походження дитини, то науковиі $i$ практики вважають, щзо вона $\epsilon$ основним елементом дитячої індивідуальності (children's identity). Так, на думку Дж. ван Б’юрен, $\epsilon$, по суті, визнанням факту їі існування, включаючи не тільки сімейні зв'язки дитини, ї̈ ім'я та громадянство, а й расову, статеву та релігійну належність.

В основі такого підходу до права на знання походження лежать повага до особистості, визнання гідності особи, що трунтуються на праві особистої ідентичності та праві на особистий розвиток. Зокрема, за результатами аналітичних розвідок було встановлено той факт, що ие право є складовою частиною людської гідності.

Визначення походнення дитини віо своїх батьків необхідне для встановлення місия $i$ ролі дитини як особистості у суспільстві й як суб'єкта у правовідносинах, особливо в сучасних умовах, коли спостерігається зростання числа розлучень; зміни в структурі традиційних сімейних відносин, що зумовлені різноманітністю форм сімейних стосунків і форм батьківства (включаючи монобатьківські сім'ї, фактичні шлюбні відносини, одностатеві шлюби), а також при народженні дитини поза шлюбом, під час усиновлення дитини, під час виховання дитини вітчимом чи мачухою, використання допоміжних репродуктивних технологій, залучення донора чи сурогатної мamepi.

Ключові слова: право, походження, інформація, репродуктивні технології, донор, міжнародний досвід.

Solodovnikova K. The right to information about the origin: foreign experience

The issue of the child's right to information about the origin is mostly discussed in the scientific literature. Whereas modern foreign experience, in particular the German one, shows that full access to this right should have a person of 16 years or over. The German doctrine of law justifies that at this age a person is more psychologically ready to perceive such information, and thus acquires expanded opportunities for its social, legal, etc. implementation.

As for information about the origin of a child, scientists and practitioners believe it to be a key element of children's identity. Thus, according to J. van Buren, it recognizes the fact of child's existence, including not only the family ties of the child, his or her name and citizenship, but also racial, sexual and religious affiliation.

Respect for the individual, recognition of the dignity of the individual, based on the right to personal identity and personal development lie at the heart of such approach to the right to information about the origin. In particular, according to the results of analytical investigations, it has been established that this right is an integral part of human dignity. 
Determining the origin of the child from his or her parents is necessary to establish the place and role of the child as a person in society and as a subject in legal relations, especially in modern conditions, when there is an increase in the number of divorces; changes in the structure of traditional family relationships due to the variety of forms of family relationships and forms of parenthood (including single-parent families, actual marital relationships, same-sex marriages), as well as cases when a child is born out of wedlock, adopted, brought up by stepfather or stepmother, born as a result of assisted reproductive technology, as well as involving a donor or surrogate mother.

Key words: right, origin, information, reproductive technology, donor, international experience.

\section{Література}

1.Hodgkin, R., Newell, P. UNICEF Implementation Handbook for the Convention on the Rights of the Child. Geneva, 2007. 787 p.

2. CHIU $V$. Le secret des origines en droit constitutionnel des H̆tats de l'Europe occidentale: Vers l'ümergence d'un droit de connaotre ses origines? Revue intrnatuonale de droit comparü. 2014. № 1. P. 68-97.

3. Конвениія про права дитини від 20.11.1989. URL: https: / / zakon.rada.gov.ua/ laws/show/995_021\#Text (Jama звернення: 08.07.2020).

4. Москаленко К. Право осіб, народжених із застосуванням допоміжних репродуктивних технологій, на інформацію про своє генетичне походження. Цивільне право і проиес. 2018. С. 27-30.

5. Гаазька конвенція про захист дітей та співробітництві щодо їх закордонного усиновлення від 29.95.1993. URL: https: / / assets.hcch.net / docs / aa0b56048ef3-49e0-a4a6-81aee50f3cb9.pdf (Jama звернення: 08.07.2020).

6. Конвенція про захист дітей ma співробітництво з питань міждержавного усиновлення. URL: http:// search.ligazakon.ua/l_doc2.nsf / link1/ MU93382.html (дата звернення: 08.07.2020).

7. Б’юрен Дж. ван. Міжнародне право в галузі прав дитини / пер. $з$ англ. Г.Є. Краснокутського ; ред. перекладу М.О. Баймуратов. Одеса : БАХВА, 2006. C. 154.

8. Європейська конвенція про усиновлення від 27.11.2008. URL: https:// zakon.rada.gov.ua/laws / show/994_ a17\#Text (дата звернення: 08.07.2020).

9. Посібник за статтею 8 Конвенціі про захист прав людини та основоположних свобод. Право на повагу до приватного і сімейного життя. 2018. 83 c. URL: http: / / www.echr.coe.int / Documents / Guide_Art_8_ENG.pdf (дата звернення: 08.07.2020).

10. Походження дитини можна перекреслити за бажанням прийомних батьків. URL: wшw.zib.com.ua (дата звернення: 08.07.2020).

11. CASE OF ODIEVRE v. FRANCE URL: https: / / hudoc.echr.coe.int / eng\#\{\% 22 docname $\%$ 22: /\% 22Odi\% C3\% A8vre\% 22 I,\%22kpthesaurus\% 22: /\% 22429\% 22 J,\% 2 2documentcollectionid $2 \% 22:$ : \% 22GRAND CHAMBER\% 22,\% 22CHAMBER\% 22 J,\% 2 2itemid\%22:/\%22001-60935\% 22J\} (Jama звернення: 10.07.2020).

12. Grundgesetz für die Bundesrepublik Deutschland. URL: https:// wrw. bundestag.de/gg (дата звернення: 10.07.2020).

13. Gesetz zum Schutz von Embryonen (Embryonenschutzgesetz - ESchG) («Пpo захист ембріонів») від 13.12.1990. URL: https: / / ww.gesetze-im-internet.de / eschg/BJNR027460990.html (Jama звернення: 09.07.2020).

14. Кравченко М.Г., Косілова О.І. Нормативно-правове регулювання права на очікуване життя: сучасний стан в Украіні та Федеративній Республіці Німеччина. Журнал східноєвропейського права. 2019. № 66. C. 26-36.

15. Gesetzzur Sicherstellungdes Embryonenschutzesim Zusammenhangmit Einfuhrund Verwendungmenschlicherembryonaler Stammzellen (Stammzellgesetz - StZG). URL: https://wwr.gesetze-im-internet. de/stzg/StZG.pdf. (дата звернення: 09.07.2020).

16. Zypries B., Zeeb M. Samenspende und das Recht des Kindes auf Kenntnis der eigenen Abstammung. Zeitschrift für Rechtspolitik. 2014. № 2. S. 54-58.

17. Консультативний висновок про визнання в національному законодавстві законних відносин батьки-дитина між дитиною, народженою за кордоном відповідно до угоди про гестаційне 


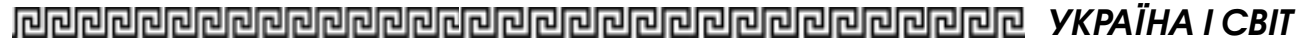

сурогатне материнство, $i$ передбачуваною матір'ю. URL: http:// hudoc.echr.coe.int / eng? $i=003-6380464$ 8364383 (дата звернення: 09.07.2020).

18. Bürgerliches Gesetzbuch (BGB). Ausfertigungsdatum: 18.08.1896. URL: www.gesetze-im-internet.de/bgb/BGB.pdf (дата звернення: 09.07.2020).

19. Herdef\&*, in: Maunz/Dürig, Art. 1 Abs. 1 GG Rn. 101; BGHZ DNotZ 2015, S. 426.

20. Bürgerliches Gesetzbuch (BGB). Ausfertigungsdatum: 18.08.1896. URL: www.gesetze-im-internet.de/bgb/BGB.pdf (дата звернення: 12.07.2020).

21. Deutsches Staatsrecht EIN STUDIENBUCH von Prof. Dr. Dr. h. c. Reinhold Zippelius em. o. Professor an der Universitat Erlangen-Nürnberg und Prof. Dr. Thomas
Würtenberger o. Professor an der Universitzt Freiburg/Brsg. 32. Auflage des von Theodor Maunz begründeten Werkes Verlag C. H. Beck München 2008. $658 \mathrm{~s}$.

22. BVerfGE 79,256,268 f.; 90,263,270 f. 23. BVerfGE 96, 56, 64 f.; zum Recht des Vaters auf ein furmliches Verfahren zur Feststellung!der Vaterschaft: BVerfGE 117, 202, 224 ff.; BVerfG NJW 2016, S. 1939, 1944f.; B. Spilker, Das Recft T auf Kenntnis der Abstammung im Verfassungsrecht, JuS 2016, S. $988 \mathrm{ff}$.

24. BGHZ NJW 2015, S. 1098 Rn. 40 ff. 3 виважуванням професійної свободи і обов'язком конфіденційності лікаря $i$ загальним правом на власну особистість при донорcmвi сперми Stmck, ff von Mangoldt/Klein/ Starck, Art. 1 Abs. 1 GG Rn. 96. 